\title{
Influence of Different Sources of Nutrient Modules on Soil Characteristics, Plant Nutrient Contents and Economics in Banana cv. Grand Naine
}

\author{
T. Ganapathi* and P.R. Dharmatti \\ Department of Horticulture, University of Agricultural Sciences, Dharwad-580 005, \\ Karnataka, India \\ *Corresponding author
}

Ke y w o r d s
Banana, INM,
Nutrient module,
Soil properties and
NPK content in
plant
Article Info
Accepted:
14 December 2017
Available Online:
10 January 2018

A B S T R A C T

A study was conducted in new orchard, Department of Horticulture, Main Agricultural Research Station (MARS), College of Agriculture, University of Agricultural Sciences, Dharwad, Karnataka during 2014-15 and 2015-16 on "Integrated nutrient management studies in banana cv. Grand Naine (AAA)" to unravel the beneficial effects of application of organic manures and chemical fertilizers with green manure, Azospirillum and PSB. At the start of experiment, the organic carbon and available NPK were medium. After the completion of the experiment the results indicated that, the organic carbon was found to be enhanced in organic treatments $\left(\mathrm{T}_{1}\right.$ to $\left.\mathrm{T}_{5}\right)$ from $0.65 \%$ to $0.72 \%$, whereas it decreased from $0.65 \%$ to $0.57 \%$ in integrated treatments $\left(\mathrm{T}_{6}\right.$ to $\left.\mathrm{T}_{12}\right)$. The available $\mathrm{N}$ and available potash in soil was significantly higher in organic treatments than integrated treatments. The available phosphorous was decreased in organic treatments compared to integrated treatments. Plants applied with $\mathrm{T}_{7}$ \{Vermicompost equivalent to $40 \% \mathrm{RDN}(24.20 \mathrm{t} / \mathrm{ha})+$ Urea equivalent to $40 \% \mathrm{RDN}(535.73 \mathrm{~kg} / \mathrm{ha})+$ Green manure (sunnhemp @ $8.88 \mathrm{t} / \mathrm{ha}$ ) and Azospirillum (30.86 kg/ha) equivalent to $20 \% \mathrm{RDN}+$ PSB $(30.86 \mathrm{~kg} / \mathrm{ha})\}$ recorded the highest NPK concentration in banana leaf, fruit and pseudostem at harvest $(3.25 \%$, $0.32 \%$ and $2.87 \%$ in leaf, $3.27 \%, 0.32 \%$ and $3.15 \%$ in fruit and $3.43 \%, 0.34 \%$ and $3.02 \%$ in pseudo stem respectively). The highest and gross returns (Rs.4.97 lakh/ha) and moderate net returns (Rs.3.04 lakh/ha) was also recorded in $\mathrm{T}_{7}$ treatment

\section{Introduction}

Banana is one of the important fruit crops known to mankind since ancient times.

In India, bananas are cultivated in an area of 0.83 million ha with a production of 30 million tonnes and its productivity is 35.9 t/ha (Anon, 2011). The major banana growing areas include Tamil Nadu, Maharashtra,
Andhra Pradesh, Gujarat, Kerala, Karnataka, West Bengal and Orissa. It is being grown in an area of 1.12 lakh ha with a production of 2.28 lakh tonnes and with a productivity of 20.40 Mt/ha in Karnataka state.

Banana is a heavy feeder of nutrients and requires large quantity of nutrients for its growth, yield and biomass production (Sridhara, 2009). The use of chemical 
fertilizers alone to feed the requirement not only become costly but also have deleterious effect on soil physical, chemical and biological properties and productivity in the long run. The availability of organic manures is one of the limitations for successful banana production. Achieving the entire nutrient requirement only through organic or inorganic or bio- fertilizers alone is seldom possible but integration of all these sources with different manures will not only aid in achieving higher yields but also in sustaining the same through enhanced soil fertility status.

\section{Materials and Methods}

The field experiments with an integrated nutrient management module consisting of organic manures, chemical fertilizers and biofertilizers on soil properties, plant nutrient contents and economics of banana cv. Grand Naine was conducted during 2014-15 and 2015-16 at new orchard, Department of Horticulture, University of Agricultural Sciences, Dharwad. The soil type is red clay. At the start of experiment, the soil organic carbon $(0.65 \%)$ and available NPK status were medium $(285,28.75$ and $156.25 \mathrm{~kg} / \mathrm{ha})$. The soil $\mathrm{pH}$ was neutral (7.38) and EC was non saline $(0.25 \mathrm{dS} / \mathrm{m})$.

The experiment consisted of 12 treatments viz.

\section{Plant crop}

$\mathrm{T}_{1-} \mathrm{FYM}$ equivalent to $40 \% \mathrm{RDN}$ (48.40 t/ha) + VC equivalent to $40 \% \mathrm{RDN}(24.20 \mathrm{t} / \mathrm{ha})+$ GM (Sunnhemp @ 8.88 t/ha) and Azospirillum $(30.86 \mathrm{~kg} / \mathrm{ha})$ equivalent to $20 \% \mathrm{RDN}+\mathrm{PSB}$ (30.86 kg/ha).

$\mathrm{T}_{2}-\mathrm{FYM}$ equivalent to $40 \% \mathrm{RDN}$ (48.40 t/ha) + PM equivalent to 40\% RDN (8.96 t/ha) + GM (Sunnhemp @ 8.88 t/ha) and Azospirillum (30.86 kg/ha) equivalent to $20 \% \mathrm{RDN}+\mathrm{PSB}$ (30.86 kg/ha).
$\mathrm{T}_{3-}$ FYM equivalent to $40 \% \mathrm{RDN}$ (48.40 t/ha) + SM equivalent to 40\% RDN (10.17 t/ha) + GM (Sunnhemp @ 8.88 t/ha) and Azospirillum $(30.86 \mathrm{~kg} / \mathrm{ha})$ equivalent to $20 \% \mathrm{RDN}+\mathrm{PSB}$ (30.86 kg/ha).

$\mathrm{T}_{4-}$ FYM equivalent to $40 \% \mathrm{RDN}$ (48.40 t/ha) + AG equivalent to 40\% RDN (10.52 t/ha) + GM (Sunnhemp @ 8.88 t/ha) and Azospirillum (30.86 kg/ha) equivalent to $20 \% \mathrm{RDN}+\mathrm{PSB}$ (30.86 kg/ha).

$\mathrm{T}_{5-}$ FYM equivalent to $40 \% \mathrm{RDN}$ (48.40 t/ha) + BL equivalent to $40 \% \mathrm{RDN}(7.56 \mathrm{t} / \mathrm{ha})+$ GM (Sunnhemp @ 8.88 t/ha) and Azospirillum (30.86 kg/ha) equivalent to $20 \% \mathrm{RDN}+\mathrm{PSB}$ (30.86 kg/ha).

$\mathrm{T}_{6-} \mathrm{FYM}$ equivalent to $40 \% \mathrm{RDN}$ (48.40 t/ha) $+40 \%$ RDN through chemical fertilizer (Urea $535.73 \mathrm{~kg} / \mathrm{ha}$ ) + GM (Sunnhemp @ $8.88 \mathrm{t} / \mathrm{ha})$ and Azospirillum (30.86 kg/ha) equivalent to $20 \% \mathrm{RDN}+\mathrm{PSB}$ (30.86 kg/ha).

$\mathrm{T}_{7-} \mathrm{VC}$ equivalent to $40 \% \mathrm{RDN}(24.20 \mathrm{t} / \mathrm{ha})+$ Chemical fertilizer (Urea $535.73 \mathrm{~kg} / \mathrm{ha}$ ) equivalent to 40\% RDN + GM (Sunnhemp @ $8.88 \mathrm{t} / \mathrm{ha}$ ) and Azospirillum (30.86 kg/ha) equivalent to $20 \% \mathrm{RDN}+\mathrm{PSB}(30.86 \mathrm{~kg} / \mathrm{ha})$.

$\mathrm{T}_{8-} \mathrm{PM}$ equivalent to $40 \% \mathrm{RDN}(8.96 \mathrm{t} / \mathrm{ha})+$ Chemical fertilizer (Urea $535.73 \mathrm{~kg} / \mathrm{ha}$ ) equivalent to 40\% RDN + GM (Sunnhemp @ $8.88 \mathrm{t} / \mathrm{ha}$ ) and Azospirillum (30.86 kg/ha) equivalent to $20 \% \mathrm{RDN}+\mathrm{PSB}(30.86 \mathrm{~kg} / \mathrm{ha})$.

$\mathrm{T}_{9 .}$ SM equivalent to $40 \% \mathrm{RDN}(10.17 \mathrm{t} / \mathrm{ha})+$ Chemical fertilizer (Urea $535.73 \mathrm{~kg} / \mathrm{ha}$ ) equivalent to 40\% RDN + GM (Sunnhemp @ $8.88 \mathrm{t} / \mathrm{ha})$ and Azospirillum (30.86 kg/ha) equivalent to $20 \% \mathrm{RDN}+\mathrm{PSB}(30.86 \mathrm{~kg} / \mathrm{ha})$.

$\mathrm{T}_{10-} \mathrm{AG}$ equivalent to $40 \% \mathrm{RDN}(10.52 \mathrm{t} / \mathrm{ha})$ + Chemical fertilizer (Urea $535.73 \mathrm{~kg} / \mathrm{ha}$ ) equivalent to 40\% RDN + GM (Sunnhemp @ $8.88 \mathrm{t} / \mathrm{ha})$ and Azospirillum (30.86 kg/ha) 
equivalent to $20 \% \mathrm{RDN}+\mathrm{PSB}(30.86 \mathrm{~kg} / \mathrm{ha})$ $\mathrm{T}_{11}$ - BL equivalent to $40 \% \mathrm{RDN}(7.56 \mathrm{t} / \mathrm{ha})+$ Chemical fertilizer (Urea $535.73 \mathrm{~kg} / \mathrm{ha}$ ) equivalent to 40\% RDN + GM (Sunnhemp @ $8.88 \mathrm{t} / \mathrm{ha})$ and Azospirillum (30.86 kg/ha) equivalent to $20 \% \mathrm{RDN}+\mathrm{PSB}(30.86 \mathrm{~kg} / \mathrm{ha})$

$\mathrm{T}_{12}$-Control (RDF 200: 100: $300 \mathrm{~g}$ NPK /plant or 617.20:308.60: $925.80 \mathrm{~kg} \mathrm{NPK/ha} \mathrm{+} \mathrm{Farm}$ yard manure@40t/ha)

The recommended dose of phosphorous and potash $(100 \mathrm{~g} / \mathrm{plant}$ and $300 \mathrm{~g} / \mathrm{plant}$ respectively) was supplied through DAP and MOP.

\section{Ratoon crop}

$\mathrm{RDF}=100: 50: 100 \quad \mathrm{NPK} \mathrm{g} /$ plant or 308.60:154.20: 308.60 kg NPK/ha) + FYM @ $20 \mathrm{t} / \mathrm{ha}$

The recommended dose of phosphorous and potash (50 g / plant and $100 \mathrm{~g} /$ plant respectively) was supplied through DAP and MOP.

The organic manures, chemical fertilizers with bio-fertilizers and green manure to compensate the majority of the plant nutrition thereby to increase the productivity of banana cv. Grand Naine.

The influence was assessed on soil properties, nutrient content of plants and economics of banana.

The results of the field experiments conducted during the year 2014-15 and 2015-16 are pooled and discussed.

\section{Results and Discussion}

The results of the field experiments conducted during the year 2014-15 and 2015-16 and pooled are presented and discussed.
Effect of different sources of nutrient modules on soil properties in banana (Table 1)

At the start of experiment, the soil organic carbon and available NPK status were medium. The soil pH was neutral and EC was non saline. After the harvest of plant crop the soil registered decline in soil $\mathrm{pH}, \mathrm{EC}$, organic carbon and available nitrogen with integrated nutrient module treatments as compared to organic nutrient modules, where it was found to increase for these parameters except in $T_{6}$. The available nitrogen was also increased in organic treatments as compared to integrated treatments including $\mathrm{T}_{12}$ where it was fond to decline in all the parameters except phosphorous. Similarly the available phosphorous was found to increase in all the treatments compared to initial status. The available potash was found to decrease in all the treatments as compared to initial status. After the harvest of ratoon crop the soil status with respect to organic carbon and available nitrogen was found to improve as compared to previous year in all the treatments. Available phosphorous and potash status was found to decrease compared to previous year.

After the completion of the experiment the pooled data indicated that, the organic carbon was found to enhance in organic treatments $\left(\mathrm{T}_{1}\right.$ to $\mathrm{T}_{5}$ ) from $0.65 \%$ to $0.72 \%$, where as it was decreased from $0.65 \%$ to $0.57 \%$ in integrated treatments $\left(\mathrm{T}_{6}\right.$ to $\left.\mathrm{T}_{12}\right)$. The available $\mathrm{N}$ in soil was significantly higher in organic treatments than integrated treatments. The available phosphorous was decreased in organic treatments compared to integrated treatments. The available potash recorded higher status in integrated nutrient modules compared to organic treatments except $T_{1}, T_{4}$ and $\mathrm{T}_{5}$ (Table 1).

Gogoi et al., (2004) reported that the combined application of inorganic fertilizer 
and bio-fertilizers in banana cv. 'Barjahaji' significantly increased the available NPK status, organic $\mathrm{C}$ and microbial biomass and dehydrogenase activity in soil after harvest. Ansari and Hazarika (2009) also reported that, the integrated use of organics with $100 \%$ recommended dose of NPK (P as rock phosphate) along with bio-fertilizers increased nitrogen, phosphorus and potassium concentration availability in soil after harvest in banana.

The results of the present study were in line with Hazarika et al., (2011). They reported that, the least $\mathrm{pH}$ was recorded in soils where the plants applied with $100 \%$ RDF + Vermicompost (4.69) and the highest organic carbon $0.85 \%$, available nitrogen 296.64 (kg/ha), available $\mathrm{P}_{2} \mathrm{O}_{5} 37.33 \quad(\mathrm{~kg} / \mathrm{ha})$ and available $\mathrm{K}_{2} \mathrm{O} 223.66$ (kg/ha)

The present study results also indicated increase in available nitrogen status in organic nutrient modules. However, in integrated nutrient modules the nitrogen status was found to decline.

This may be attributed to the higher uptake of nutrients in turn higher yield obtained in these integrated treatments as compared to organic treatments.

According to Virendra Kumar and Mishra (1991) available phosphorus decreased due to application of carbonation press mud. This indicates that, the application of organic nutrient modules would reduce the available phosphorous as found in the present study. Kale et al., (1992) also found that combined application of vermicompost with NPK fertilizers resulted in higher content of phosphorous as compared to FYM in combination with NPK fertilizers or control. Balaji (1994) recorded higher levels of available phosphorous in the treatments which received either vermicompost or FYM in combination with chemical fertilizers than control. Similar results were also recorded in the present study where integrated nutrient modules were imposed compared to organic nutrient modules. The integrated nutrient module would maintain the available potash or might increase as compared to the organic nutrient treatment which was confirmed with the present study results.

\section{Effect of different sources of nutrient modules on plant nutrient contents in banana (Table 2)}

The pooled data indicated that the highest leaf nitrogen was recorded in $\mathrm{T}_{7}(3.25 \%)$ and $\mathrm{T}_{10}$ $(3.23 \%)$ which was significantly superior over rest of the treatments. The phosphorous content in leaf was highest in $\mathrm{T}_{7}(0.32 \%)$ which was on par with $\mathrm{T}_{10}, \mathrm{~T}_{11}$ and $\mathrm{T}_{6}$ and significantly superior over rest of the treatments.

The higher potash content in leaf was recorded in $\mathrm{T}_{7}$ treatment $(2.87 \%)$ which was significantly superior over rest of the treatments. The organic treatments recorded comparatively low nitrogen and phosphorous content in leaf compared to integrated nutrient modules.

The pooled data indicated that the highest nitrogen in fruit was recorded in $\mathrm{T}_{10}(3.31 \%)$ which was on par with $\mathrm{T}_{7}(3.27 \%)$ followed by $\mathrm{T}_{11}(3.11 \%)$. The phosphorous content in fruit was highest in $\mathrm{T}_{7}(0.32 \%)$ which was on par with $\mathrm{T}_{10}$ and $\mathrm{T}_{11}$ and significantly superior over rest of the treatments.

The higher potash content in fruit was recorded in $\mathrm{T}_{7}$ treatment $(3.22 \%$ ) which was significantly superior over rest of the treatments. The organic treatments recorded comparatively low nitrogen, phosphorous and potash contents in fruit compared to integrated nutrient modules. 
Table.1 Influence of different sources of nutrient modules on soil characteristics in banana cv. Grand Naine (Pooled mean)

\begin{tabular}{|c|c|c|c|c|c|c|}
\hline Treatments & Soil pH (1:2.5) & $\mathrm{EC}(\mathrm{dS} / \mathrm{m})$ & Organic C (\%) & Avail N (kg/ha) & $\begin{array}{c}\text { Avail } \mathbf{P}_{2} \mathbf{O}_{5} \\
\text { (kg/ha) }\end{array}$ & Avail $K_{2} O(\mathrm{Kg} / \mathrm{ha})$ \\
\hline $\mathbf{T}_{1}$ & 7.24 & 0.14 & 0.72 & 319.95 & 24.05 & 133.50 \\
\hline $\mathbf{T}_{2}$ & 7.27 & 0.11 & 0.68 & 302.95 & 22.50 & 118.80 \\
\hline $\mathbf{T}_{3}$ & 7.34 & 0.12 & 0.69 & 306.68 & 23.90 & 118.65 \\
\hline $\mathbf{T}_{4}$ & 7.16 & 0.12 & 0.70 & 311.25 & 21.55 & 133.35 \\
\hline $\mathbf{T}_{5}$ & 6.98 & 0.16 & 0.71 & 314.98 & 23.90 & 132.90 \\
\hline$T_{6}$ & 6.93 & 0.11 & 0.57 & 264.48 & 28.20 & 118.90 \\
\hline $\mathbf{T}_{7}$ & 6.91 & 0.11 & 0.59 & 271.53 & 30.70 & 130.85 \\
\hline $\mathbf{T}_{8}$ & 7.37 & 0.10 & 0.58 & 268.20 & 26.30 & 125.80 \\
\hline $\mathbf{T}_{9}$ & 7.07 & 0.14 & 0.59 & 271.10 & 28.20 & 118.60 \\
\hline $\mathbf{T}_{10}$ & 7.04 & 0.12 & 0.61 & 281.88 & 29.30 & 123.65 \\
\hline $\mathbf{T}_{11}$ & 7.20 & 0.11 & 0.59 & 271.93 & 28.80 & 130.85 \\
\hline $\mathbf{T}_{12}$ & 7.11 & 0.16 & 0.63 & 285.18 & 30.70 & 130.40 \\
\hline S Em+/- & 0.02 & 0.01 & 0.01 & 1.73 & 0.80 & 0.68 \\
\hline CD at $5 \%$ & 0.06 & 0.02 & 0.01 & 5.08 & 2.36 & 2.00 \\
\hline
\end{tabular}

T . FYM equivalent to 40\% RDN (48.40 t/ha) + VC equivalent to 40\% RDN (24.20 t/ha)+ GM (sunnhemp @ 8.88 t/ha) and Azospirillum (@ 30.86 kg/ha) equivalent to 20\% RDN + PSB (@ 30.86 $\mathrm{kg} / \mathrm{ha}$ ).

$\mathrm{T}_{2}$-FYM equivalent to 40\% RDN (48.40 t/ha) + PM equivalent to 40\% RDN (8.96 t/ha) + GM (sunnhemp @ 8.88 t/ha) and Azospirillum (@ 30.86 kg/ha) equivalent to 20\% RDN + PSB (@ 30.86 $\mathrm{kg} / \mathrm{ha}$ ).

T3-FYM equivalent to 40\% RDN (48.40 t/ha) + SM equivalent to 40\% RDN (10.17 t/ha)+ GM (sunnhemp @ 8.88 t/ha) and Azospirillum (@ 30.86 kg/ha) equivalent to 20\% RDN + PSB (@ 30.86

$\mathrm{kg} / \mathrm{ha}$ ).

T. FYM equivalent to 40\% RDN (48.40 t/ha) + AG equivalent to 40\% RDN (10.52 t/ha) + GM (sunnhemp @ 8.88 t/ha) and Azospirillum (@30.86kg/ha) equivalent to 20\% RDN + PSB (@

$30.86 \mathrm{~kg} / \mathrm{ha})$.

$\mathrm{T}_{5-}$ FYM equivalent to 40\% RDN (48.40 t/ha) + BL equivalent to 40\% RDN (7.56 t/ha) + GM (Sun hemp @ 8.88 t/ha) and Azospirillum (@ 30.86kg/ha) equivalent to 20\% RDN + PSB (@ 30.86kg/ha). $\mathrm{T}_{6}$ FYM equivalent to 40\% RDN (48.40 t/ha) + 40\% RDN through chemical fertilizer (Urea 535.73 kg/ ha) + GM (sunnhemp @8.88 t/ha) and Azospirillum (@30.86 kg/ha) equivalent to 20\% RDN + PSB (@ 30.86kg/ha).

T 7. VC equivalent to 40\% RDN (24.20 t/ha) + 40\% RDN through chemical fertilizer (Urea 535.73 kg/ ha) + GM (sunnhemp@ 8.88 t/ha) + Azospirillum (@ 30.86kg/ha) equivalent to 20\% RDN + PSB (@ $30.86 \mathrm{~kg} / \mathrm{ha})$.

T . PM equivalent to 40\% RDN (8.96 t/ha)+ 40\% RDN through chemical fertilizer (Urea $535.73 \mathrm{~kg} / \mathrm{ha}$ ) + GM (sunnhemp @ 8.88 t/ha) and Azospirillum (@ 30.86 kg/ha) equivalent to 20\% RDN + PSB (@ $30.86 \mathrm{~kg} / \mathrm{ha})$.

T. SM equivalent to 40\% RDN (10.17 t/ha) + 40\% RDN through chemical fertilizer (Urea 535.73 kg/ ha) + GM (sunnhemp @ 8.88 t/ha) and Azospirillum (@ 30.86 kg/ha)equivalent to 20\% RDN + PSB (@ $30.86 \mathrm{~kg} / \mathrm{ha})$.

$\mathrm{T}_{10}$ - AG equivalent to 40\% RDN (10.52 t/ha) + 40\% RDN through chemical fertilizer (Urea $535.73 \mathrm{~kg} / \mathrm{ha}$ ) + GM (sunnhemp @ 8.88 t/ha) and Azospirillum (@ $30.86 \mathrm{~kg} / \mathrm{ha}$ )equivalent to 20\% RDN + PSB (@30.86 kg/ha

$\mathrm{T}_{11-}$ BL equivalent to 40\% RDN (7.56 t/ha) + 40\% RDN through chemical fertilizer (Urea $535.73 \mathrm{~kg} / \mathrm{ha}$ ) + GM (sunnhemp @ 8.88 t/ha) and Azospirillum (@30.86 kg/ha) equivalent to 20\% RDN + PSB (@30.86 kg/ha)

$\mathrm{T}_{12}$-Control (RDF=617.20:308.60: $925.80 \mathrm{~kg} \mathrm{NPK} / \mathrm{ha}+$ Farm yard manure@ $40 \mathrm{t} / \mathrm{ha}$ (plant crop)

Ratoon crop: RDF=308.60:154.20: $308.60 \mathrm{~kg} \mathrm{NPK} / \mathrm{ha}$ ) + FYM @ 20/ha accordingly it has been supplied through different sources

FYM- Farmyard manure, VC-Vermicompost, PM-Poultry manure, SM-Sheep manure, AG-Agrigold, BL-Bhumilabh, GM-Green manure, PSB-Phosphate Solubilizing bacteria 
Table.2 Influence of different sources of nutrient modules on nutrient concentration (\%) in banana cv. Grand Naine (Pooled mean)

\begin{tabular}{|c|c|c|c|c|c|c|c|c|c|}
\hline \multirow[t]{2}{*}{ Treatments } & \multicolumn{3}{|c|}{ Leaf } & \multicolumn{3}{|c|}{ Fruit } & \multicolumn{3}{|c|}{ Stem } \\
\hline & $\mathbf{N}$ & $\mathbf{P}$ & $\mathbf{K}$ & $\mathbf{N}$ & $\mathbf{P}$ & $\mathbf{K}$ & $\mathbf{N}$ & $\mathbf{P}$ & $\mathbf{K}$ \\
\hline $\mathrm{T}_{1}$ & 2.57 & 0.24 & 2.33 & 2.67 & 0.25 & 2.55 & 2.81 & 0.24 & 2.64 \\
\hline $\mathrm{T}_{2}$ & 2.30 & 0.23 & 2.21 & 2.13 & 0.23 & 2.43 & 2.22 & 0.25 & 2.46 \\
\hline $\mathbf{T}_{3}$ & 2.26 & 0.21 & 2.14 & 1.64 & 0.22 & 2.43 & 1.72 & 0.24 & 2.41 \\
\hline$T_{4}$ & 2.55 & 0.23 & 2.29 & 2.31 & 0.23 & 2.52 & 2.43 & 0.25 & 2.59 \\
\hline $\mathbf{T}_{5}$ & 2.45 & 0.23 & 2.24 & 2.32 & 0.23 & 2.44 & 2.41 & 0.24 & 2.51 \\
\hline$T_{6}$ & 3.01 & 0.28 & 2.48 & 3.06 & 0.29 & 2.73 & 3.18 & 0.30 & 2.83 \\
\hline $\mathbf{T}_{7}$ & 3.25 & 0.32 & 2.87 & 3.27 & 0.32 & 3.22 & 3.43 & 0.34 & 3.32 \\
\hline $\mathrm{T}_{8}$ & 2.09 & 0.20 & 2.04 & 1.60 & 0.20 & 2.27 & 1.69 & 0.21 & 2.24 \\
\hline$T_{9}$ & 2.95 & 0.25 & 2.42 & 2.67 & 0.25 & 2.70 & 2.81 & 0.27 & 2.73 \\
\hline $\mathrm{T}_{10}$ & 3.23 & 0.30 & 2.75 & 3.31 & 0.30 & 3.03 & 3.42 & 0.32 & 3.15 \\
\hline$T_{11}$ & 3.07 & 0.29 & 2.62 & 3.11 & 0.30 & 2.91 & 3.25 & 0.32 & 3.00 \\
\hline$T_{12}$ & 2.96 & 0.25 & 2.47 & 2.98 & 0.25 & 2.77 & 3.12 & 0.27 & 2.79 \\
\hline S. Em. \pm & 0.02 & 0.01 & 0.01 & 0.01 & 0.01 & 0.05 & 0.02 & 0.01 & 0.04 \\
\hline C.D. at 5\% & 0.05 & 0.04 & 0.04 & 0.04 & 0.03 & 0.15 & 0.06 & 0.04 & 0.12 \\
\hline
\end{tabular}

T . FYM equivalent to $40 \%$ RDN (48.40 t/ha) + VC equivalent to $40 \%$ RDN (24.20 t/ha) + GM (sunnhemp @ 8.88 t/ha) and Azospirillum (@ 30.86 kg/ha) equivalent to $20 \%$ RDN + PSB (@ 30.86 $\mathrm{kg} / \mathrm{ha})$.

T -FYM equivalent to 40 \% RDN (48.40 t/ha) + PM equivalent to 40 \% RDN (8.96 t/ha) + GM (sunnhemp @ 8.88 t/ha) and Azospirillum (@ 30.86 kg/ha) equivalent to $20 \%$ RDN + PSB (@30.86 $\mathrm{kg} / \mathrm{ha})$.

T3. FYM equivalent to $40 \%$ RDN (48.40 t/ha) + SM equivalent to 40 \% RDN (10.17 t/ha)+ GM (sunnhemp @ 8.88 t/ha) and Azospirillum (@ 30.86 kg/ha) equivalent to $20 \%$ RDN + PSB (@ 30.86 T3-FYMe

T. FYM equivalent to 40 \% RDN (48.40 t/ha) + AG equivalent to 40 \% RDN (10.52 t/ha) + GM (sunnhemp @ 8.88 t/ha) and Azospirillum (@30.86 kg/ha) equivalent to $20 \%$ RDN + PSB (@30.86 $\mathrm{kg} / \mathrm{ha}$ ).

T5- FYM equivalent to $40 \%$ RDN (48.40 t/ha) + BL equivalent to 40 \% RDN (7.56 t/ha) + GM (Sunnhemp @ 8.88 t/ha) and Azospirillum (@ 30.86 kg/ha) equivalent to $20 \%$ RDN + PSB (@ 30.86 $\mathrm{kg} / \mathrm{ha})$.

$\mathrm{T}_{6}$ FYM equivalent to 40 \% RDN (48.40 t/ha) + 40 \% RDN through chemical fertilizer (urea 535.73 kg/ ha) + GM (sunnhemp @ 8.88 t/ha) and Azospirillum (@ 30.86 kg/ha) equivalent to 20\% RDN + PSB (@30.86 kg/ha).

T 7. VC equivalent to $40 \%$ RDN (24.20 t/ha) + 40 \% RDN through chemical fertilizer (urea 535.73 kg/ ha) + GM (sunnhemp@ 8.88 t/ha) and Azospirillum (@ 30.86 kg/ha) equivalent to 20\% RDN + PSB $(@ 30.86 \mathrm{~kg}$ h)

$\mathrm{T}_{8 \text { - }}$ PM equivalent to $40 \% \mathrm{RDN}(8.96 \mathrm{t} / \mathrm{ha}$ ) + $40 \%$ RDN through chemical fertilizer (urea $535.73 \mathrm{~kg} / \mathrm{ha}$ ) + GM (sunnhemp @ $8.88 \mathrm{t} / \mathrm{ha}$ ) and Azospirillum (@ $30.86 \mathrm{~kg} / \mathrm{ha}$ ) equivalent to $20 \% \mathrm{RDN}+$ PSB (@30.86 kg/ha).

$\mathrm{T}_{9}$. SM equivalent to $40 \%$ RDN (10.17 t/ha) + 40 \% RDN through chemical fertilizer (urea $535.73 \mathrm{~kg} / \mathrm{ha}$ ) + GM (sunnhemp @8.88 t/ha) and Azospirillum (@ $30.86 \mathrm{~kg} / \mathrm{ha}$ ) equivalent to $20 \%$ RDN + PSB (@ $30.86 \mathrm{~kg} / \mathrm{ha})$

$\mathrm{T}_{10}$ - AG equivalent to $40 \% \mathrm{RDN}(10.52 \mathrm{t} / \mathrm{ha})+40 \% \mathrm{RDN}$ through chemical fertilizer (urea $\left.535.73 \mathrm{~kg} / \mathrm{ha}\right)+\mathrm{GM}$ (sunnhemp @ $\left.8.88 \mathrm{t} / \mathrm{ha}\right)$ and Azospirillum (@ $\left.30.86 \mathrm{~kg} / \mathrm{ha}\right)$ equivalent to $20 \% \mathrm{RDN}+$ PSB (@ $30.86 \mathrm{~kg} / \mathrm{ha}$

$\mathrm{T}_{11}$. BL equivalent to $40 \% \mathrm{RDN}$ (7.56 t/ha) + $40 \%$ RDN through chemical fertilizer (urea $535.73 \mathrm{~kg} / \mathrm{ha}$ ) + GM (sunnhemp @ $8.88 \mathrm{t} / \mathrm{ha}$ ) and Azospirillum (@ $30.86 \mathrm{~kg} / \mathrm{ha}$ ) equivalent to $20 \%$ RDN + PSB (@30.86 kg/ha)

$\mathrm{T}_{12}$-Control (RDF=617.20:308.60: $925.80 \mathrm{~kg} \mathrm{NPK} / \mathrm{ha}+$ Farm yard manure@ $40 \mathrm{t} / \mathrm{ha}$ (plant crop)

Ratoon crop: RDF=308.60:154.20: $308.60 \mathrm{~kg} \mathrm{NPK/ha)} \mathrm{+} \mathrm{FYM} \mathrm{@} \mathrm{20/ha} \mathrm{accordingly} \mathrm{it} \mathrm{has} \mathrm{been} \mathrm{supplied} \mathrm{through} \mathrm{different} \mathrm{sources}$

FYM- Farmyard manure, VC-Vermicompost, PM-Poultry manure, SM-Sheep manure, AG-Agrigold, BL-Bhumilabh, GM-Green manure, PSB-Phosphate Solubilizing bacteria 
Table.3 Influence of different sources of nutrient modules on economics of banana cv. Grand Naine (Pooled mean)

\begin{tabular}{|c|c|c|c|c|}
\hline Treatments & GC (Rs) & GR (Rs) & NR (Rs) & B:C ratio \\
\hline$T_{1}$ & $1,72,070$ & $4,25,377$ & $2,53,307$ & 2.45 \\
\hline $\mathbf{T}_{2}$ & $1,41,057$ & $3,51,422$ & $2,10,365$ & 2.49 \\
\hline $\mathbf{T}_{3}$ & $1,47,347$ & $3,39,108$ & $1,91,761$ & 2.30 \\
\hline $\mathbf{T}_{4}$ & $1,84,279$ & $4,22,733$ & $2,38,454$ & 2.29 \\
\hline $\mathbf{T}_{5}$ & $2,07,715$ & $4,06,747$ & $1,99,032$ & 1.96 \\
\hline$T_{6}$ & $1,68,454$ & $4,09,822$ & $2,41,368$ & 2.43 \\
\hline $\mathbf{T}_{7}$ & $1,92,654$ & $4,97,621$ & $3,04,967$ & 2.58 \\
\hline $\mathrm{T}_{8}$ & $1,29,016$ & $3,58,638$ & $2,29,622$ & 2.78 \\
\hline$T_{9}$ & $1,35,306$ & $4,11,605$ & $2,76,299$ & 3.04 \\
\hline$T_{10}$ & $1,72,238$ & $4,90,095$ & $3,17,857$ & 2.85 \\
\hline$T_{11}$ & $1,95,674$ & $4,28,279$ & $2,32,605$ & 2.19 \\
\hline $\mathbf{T}_{12}$ & $1,21,164$ & $4,13,830$ & $2,92,667$ & 3.42 \\
\hline S Em+/- & - & 24394 & 24395 & 0.14 \\
\hline CD at $5 \%$ & - & 71546 & 71546 & 0.41 \\
\hline
\end{tabular}

Banana fruit selling price (Rs/t): plant crop Rs.8,000 and ratoon crop Rs.7,000

GC: Gross cost, GR: Gross returns, NR: Net returns and B: C ratio benefit : cost ratio

$\mathrm{T}_{1 .}$ FYM equivalent to $40 \%$ RDN (48.40 t/ha) + VC equivalent to $40 \%$ RDN (24.20 t/ha) + GM (sunnhemp @ 8.88 t/ha) and Azospirillum (@ 30.86 kg/ha) equivalent to $20 \%$ RDN + PSB (@ 30.86 $\mathrm{kg} / \mathrm{ha})$.

T2-FYM equivalent to 40 \% RDN (48.40 t/ha) + PM equivalent to 40 \% RDN (8.96 t/ha) + GM (sunnhemp @ 8.88 t/ha) and Azospirillum (@ 30.86 kg/ha) equivalent to $20 \%$ RDN + PSB (@ 30.86 $\mathrm{kg} / \mathrm{ha})$.

T.-FYM equivalent to 40 \% RDN (48.40 t/ha) + SM equivalent to 40 \% RDN (10.17 t/ha) + GM (sunnhemp @ 8.88 t/ha) and Azospirillum (@ 30.86 kg/ha) equivalent to 20 \% RDN + PSB (@30.86 $\mathrm{kg} / \mathrm{ha})$.

T. FYM equivalent to 40 \% RDN (48.40 t/ha) + AG equivalent to 40 \% RDN (10.52 t/ha)+GM (sunnhemp @ 8.88 t/ha) and Azospirillum (@ 30.86 kg/ha) equivalent to 20 \% RDN + PSB (@30.86 $\mathrm{kg} / \mathrm{ha})$.

T5- FYM equivalent to 40 \% RDN (48.40 t/ha) + BL equivalent to 40 \% RDN (7.56 t/ha) + GM (Sunnhemp @ 8.88 t/ha) and Azospirillum (@30.86 kg/ha) equivalent to 20\% RDN + PSB (@ 30.86 $\mathrm{kg} / \mathrm{ha}$ ).

$\mathrm{T}_{6} \mathrm{FYM}$ equivalent to $40 \% \mathrm{RDN}(48.40 \mathrm{t} / \mathrm{ha})+40 \% \mathrm{RDN}$ through chemical fertilizer (urea $\left.535.73 \mathrm{~kg} / \mathrm{ha}\right)+\mathrm{GM}$ (sunnhemp @ $8.88 \mathrm{t} / \mathrm{ha}$ ) and Azospirillum (@ $\left.30.86 \mathrm{~kg} / \mathrm{ha}\right)$ equivalent to $20 \% \mathrm{RDN}+$ PSB (@ $30.86 \mathrm{~kg} / \mathrm{ha})$.

$\mathrm{T}_{7}$. VC equivalent to $40 \% \mathrm{RDN}$ (24.20 t/ha) + 40 \% RDN through chemical fertilizer (urea $535.73 \mathrm{~kg} / \mathrm{ha}$ ) + GM (sunnhemp@ 8.88 t/ha) and Azospirillum (@ $30.86 \mathrm{~kg} / \mathrm{ha}$ ) equivalent to $20 \%$ RDN + PSB (@30.86 kg/ha).

$\mathrm{T}_{8 \text { - }}$ PM equivalent to $40 \% \mathrm{RDN}(8.96 \mathrm{t} / \mathrm{ha})+40 \% \mathrm{RDN}$ through chemical fertilizer (urea $\left.535.73 \mathrm{~kg} / \mathrm{ha}\right)+\mathrm{GM}$ (sunnhemp @ $\left.8.88 \mathrm{t} / \mathrm{ha}\right)$ and Azospirillum (@ $\left.30.86 \mathrm{~kg} / \mathrm{ha}\right)$ equivalent to $20 \% \mathrm{RDN}+$ PSB (@30.86 kg/ha).

$\mathrm{T}_{\text {9. }}$ SM equivalent to $40 \% \mathrm{RDN}$ (10.17 t/ha) + $40 \%$ RDN through chemical fertilizer (urea $535.73 \mathrm{~kg} / \mathrm{ha}$ ) + GM (sunnhemp @ 8.88 t/ha) and Azospirillum (@ $30.86 \mathrm{~kg} / \mathrm{ha}$ ) equivalent to $20 \%$ RDN + PSB (@30.86 kg/ha).

$\mathrm{T}_{10}$. AG equivalent to $40 \%$ RDN (10.52 t/ha) + 40 \% RDN through chemical fertilizer (urea $535.73 \mathrm{~kg} / \mathrm{ha}$ ) + GM (sunnhemp @ $\left.8.88 \mathrm{t} / \mathrm{ha}\right)$ and Azospirillum (@ $30.86 \mathrm{~kg} / \mathrm{ha}$ ) equivalent to 20\% RDN + PSB (@30.86 kg/ha

$\mathrm{T}_{11}$. BL equivalent to $40 \%$ RDN (7.56 t/ha) + $40 \%$ RDN through chemical fertilizer (urea $535.73 \mathrm{~kg} / \mathrm{ha}$ ) + GM (sunnhemp @ 8.88 t/ha) and Azospirillum (@ $30.86 \mathrm{~kg} / \mathrm{ha}$ ) equivalent to $20 \%$ RDN + PSB (@ $30.86 \mathrm{~kg} / \mathrm{ha})$

$\mathrm{T}_{12}$-Control (RDF=617.20:308.60: $925.80 \mathrm{~kg} \mathrm{NPK/ha}+$ Farm yard manure@ 40 t/ha (plant crop)

Ratoon crop: RDF=308.60:154.20: $308.60 \mathrm{~kg}$ NPK/ha) + FYM @ 20/ha accordingly it has been supplied through different sources

FYM- Farmyard manure, VC-Vermicompost, PM-Poultry manure, SM-Sheep manure, AG-Agrigold, BL-Bhumilabh, GM-Green manure, PSB-Phosphate Solubilizing bacteria 
The pooled data indicated that the highest nitrogen in stem was recorded in $\mathrm{T}_{7}(3.43 \%)$ which was significantly superior over rest of the treatments. The phosphorous content in stem was highest in $\mathrm{T}_{7}(0.34 \%)$ which was on par with $\mathrm{T}_{10}, \mathrm{~T}_{11}$ and $\mathrm{T}_{6}$ and significantly superior over rest of the treatments. The higher potash content in stem was recorded in $\mathrm{T}_{7}$ treatment $(3.32 \%)$ which was significantly superior over rest of the treatments (Table 2). The integrated nutrient modules recorded the superior nitrogen, phosphorous and potash contents in stem compared to organic treatments.

Among the different plant parts, the nitrogen content of leaf was higher compared to fruit and stem. The phosphorous content of fruit was higher compared to leaf and stem. The potash content in banana pseudostem was superior compared to fruit and leaf in all the treatments.

The present study results were in line with the results reported by Ansari and Hazarika (2009). They opined that, the integrated use of organics with $100 \%$ recommended dose of NPK (P as rock phosphate) along with bio-fertilizers increased nitrogen, phosphorus and potassium concentration in banana plant.

\section{Effect of different sources of nutrient modules on economics of banana (Table 3 )}

Banana crop is an exhaustive commercial horticultural crop which is grown for two-tothree years from single planting. The nutrient management plays a major role in its cultivation. The nutrient module which fetches higher returns as well as on par benefit: cost ratio as that of highest returns and highest benefit: cost ratio can be adopted for cultivation of banana.

The pooled economic analysis of treatments revealed that the lowest gross cost (Rs.1.29 lakh/ha) was incurred in the treatment $\mathrm{T}_{8}$ \{Poultry manure equivalent to $40 \% \mathrm{RDN}$ (8.96 t/ha) $+40 \%$ RDN through chemical fertilizer (urea $535.73 \mathrm{~kg} / \mathrm{ha}$ ) + Green manure (sunnhemp @ 8.88 t/ha) and Azospirillum
(30.86 kg/ha) equivalent to $20 \% \mathrm{RDN}+\mathrm{PSB}$ $(30.86 \mathrm{~kg} / \mathrm{ha})\}$. The treatment $\mathrm{T}_{7}$ \{Vermicompost equivalent to $40 \%$ RDN (24.20 $\mathrm{t} / \mathrm{ha})+40 \% \mathrm{RDN}$ through chemical fertilizer (urea $535.73 \mathrm{~kg} / \mathrm{ha}$ ) + Green manure (sunnhemp @ 8.88 t/ha) and Azospirillum $(30.86 \mathrm{~kg} / \mathrm{ha})$ equivalent to $20 \% \mathrm{RDN}+\mathrm{PSB}$ $(30.86 \mathrm{~kg} / \mathrm{ha})\}$ recorded the highest gross returns (Rs.4.97 lakh/ha). The highest net returns $\{$ Rs.3.17 lakh/ha $\}$ in $\mathrm{T}_{10}$ \{Agrigold equivalent to $40 \% \mathrm{RDN}(10.52 \mathrm{t} / \mathrm{ha})+40 \%$ RDN through chemical fertilizer (urea 535.73 $\mathrm{kg} / \mathrm{ha}$ ) + Green manure (sunnhemp @ 8.88 t/ha) and Azospirillum (30.86 kg/ha) equivalent to $20 \% \mathrm{RDN}+\mathrm{PSB}(30.86 \mathrm{~kg} / \mathrm{ha})$ ) followed by $\mathrm{T}_{7}$ (Rs.3.04 lakh/ha). The highest benefit: cost ratio (3.42) was recorded in $\mathrm{T}_{12}\{\mathrm{RDF}=$ 617: 308.6: $925.8 \mathrm{~kg}$ NPK /ha) + Farmyard manure (@ $40.00 \mathrm{t} / \mathrm{ha}$ ) followed by $\mathrm{T}_{9}, \mathrm{~T}_{10}, \mathrm{~T}_{8}$ and $\mathrm{T}_{7}(3.04,2.85,2.78$ and 2.58 respectively) treatments. The treatment $\mathrm{T}_{7}$ (vermicompost combination) recorded moderate net returns (3.04 lakh/ ha) and B: C ratio (2.58) and is considered to be good due to the fact that if vermicompost is produced by farmers themselves the $\mathrm{BC}$ ratio can also be improved.

Bhalerao et al., (2009) reported that application of $100 \%$ recommended dose of NPK with 10 kg FYM per plant and bio-fertilizers (Azospirillum and PSB at $25 \mathrm{~g}$ each per plant) was found beneficial in terms financial returns with highest benefit cost ratio (1.48) in banana cv. Grand Naine.

Tangaselvabai et al., (2009) also reported that treatment with 100:30:330 $\mathrm{g} \mathrm{NPK} /$ plant in 2 splits + Azospirillum was found to be superior for increased net profit (Rs/ha) and benefit: cost ratio. The integrated nutrient modules would be superior in obtaining higher net profit and on par benefit: cost ratio as compared to the control treatment $(100 \%$ RDF + FYM).

Kuttimani et al., (2013b) reported that, higher gross returns of Rs. 3,63,850/- and Rs.3,85,600/- was recorded during 2010-11 and 2011-12 respectively with the application of 100 per cent recommended dose of fertilizer 
along with $40 \%$ Wellgro soil and the net return was higher (Rs. 2,25,403/- and Rs. 2,48,364/-) with the application of $100 \%$ recommended dose of fertilizer along with $40 \%$ Well grow soil. The benefit-cost ratio was higher (2.63) with $40 \%$ Well grow soil $+100 \%$ RDF. The results of the present study also indicated higher gross returns when integrated nutrient modules were followed. However, the organic nutrient modules registered lesser gross returns owing to the fact that the banana crop is an exhaustive crop which might not be coped up by organics alone.

The integrated nutrient modules favoured higher nutrient concentrations of NPK in different plant parts of banana through higher soil availability of nutrients and in turn yield. Therefore the higher yield per hectare was obtained in $\mathrm{T}_{7}$ (with Vermicompost combination), $\mathrm{T}_{10}$ (with Agri-gold combination) and $\mathrm{T}_{11}$ (with Bhumilabh combination) indicating the potentiality of these organic manures when used in conjunction with chemical and bio- fertilizers. The treatment $\mathrm{T}_{7}$ recorded the highest gross returns (Rs.4.97 lakh/ha) and moderate net returns (Rs.3.04 lakh/ha). However, the $\mathrm{B}$ : $\mathrm{C}$ ratio was highest in control $\left(\mathrm{T}_{12}, 3.42\right)$.

\section{References}

Anonymous, 2011. National Horticulture Board. Department of Agriculture and Cooperation, Ministry of Agriculture, Govt. of India, New Delhi.

Ansari, S. and Hazarika, B. N., 2009. Effect of integrated nutrient management on leaf nutrient content in banana and nutrient availability in soil after harvest. Environ. Ecol., 27(2): 553-556.

Balaji, S. K., 1994. Effect of vermicompost on growth and flower yield of China aster
(Callistephus chinensis). M. Sc. (Agri.) Thesis, Univ. Agric. Sci., Dharwad, Karnataka (India).

Bhalerao, V. P., Patil, N. M., Badgujar, C. D. and Patil, D. R., 2009. Studies on integrated nutrient management for tissue cultured Grand Naine banana. Indian J. Agric. Res., 43 (2):107-112.

Gogoi, D., Kotoky, U. and Hazarika, S., 2004. Effect of bio-fertilizers on productivity and soil characteristics in banana. India J. Hort. 61: 354-356.

Hazarika, T. K., Nautiyal, B. P. and Bhattacharya, R. K., 2011. Effect of INM on productivity and soil characteristics of tissue cultured banana cv. Grand Naine in Mizoram, India. Indian J. Hort. 43(1): 30-35.

Kale, R. D., Mallesh, B. C., Bano, K. and Bhagyaraj, D. J., 1992. Influence of Vermicompost application on available micro nutrients and selected microbial population in a paddy field soil. Bio and Biochem, 29(12): 1317-1320.

Kuttimani, R., Velayudham, K., Somasundaram E. and Muthukrishnan, P. 2013b. Effect of integrated nutrient management on yield and economics of banana. Global Journal of Biology, Agriculture and Health Sciences., 2(4):191-195.

Sridhara, R., 2009. Integrated nutrient management in hill banana cv. Virupakshi. M. Sc. (Hort.) Thesis, Horticultural College and Research Institute, TNAU, Periyakulam, Tamil Nadu (India).

Tangaselvabai, T., Gailice leo justin, C., Nirmal Johnson, S.B. and Jayasekhar, M., 2009. Influence of nutrients on qualitative and quantitative traits of banana. Indian $J$. Agric. Res. 43(4): 274-278.

Virendra Kumar and Mishra, B., 1991. Effect of two types of Press mud cake on growth of rice- maize and soil properties. Indian Soc. Soil Sci., 39: 109-113.

\section{How to cite this article:}

Ganapathi, T. and Dharmatti, P.R. 2018. Influence of Different Sources of Nutrient Modules on Soil Characteristics, Plant Nutrient Contents and Economics in Banana cv. Grand Naine. Int.J.Curr.Microbiol.App.Sci. 7(01): 1995-2003. doi: https://doi.org/10.20546/ijcmas.2018.701.241 